\title{
A dobre cara das tecnoloxías da comunicación: libérannos e contrólannos
}

institucionales.us.es/ambitos/

\section{Xosé López}

Universidade de Santiago de Compostela xose.lopez.garcia@usc.es

Dos dimensiones de las tecnologías de la información y la comunicación (TIC) se han convertido en otros tantos pilares que alimentan el imaginario de la sociedad red en los tiempos de la denominada automatización inteligente. Nos liberan y nos empoderan en el escenario digital, pero al mismo tiempo nos controlan y, a veces, nos desconciertan. Al igual que el dios Jano en la mitología romana, ofrecen dos caras que representan fortalezas y amenazas del pasado y del futuro.

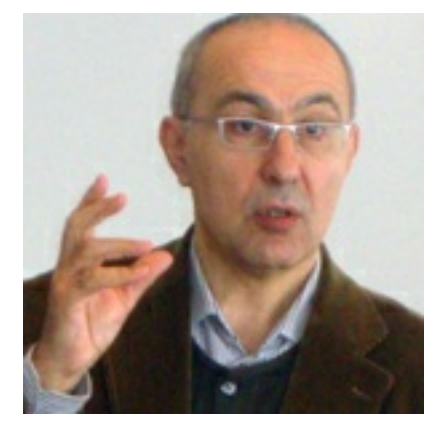

De las diversas fases tecnológicas que han marcado la historia de la Comunicación, la actual, que emerge alrededor de las TIC, la digitalización, internet y la sociedad red, no solo ha conseguido cambiar paradigmas sino que ha hecho posible que las audiencias sean realmente activas y que la autocomunicación ocupe un lugar relevante en el ecosistema mediático. Paralelamente, en estos años hemos visto como el software ha consolidado su posición en el vértice de mando.

Desde sus orígenes, la tecnología ha surgido como la respuesta y construcción de los humanos a necesidades o desafíos. El reto de la superación, con objetivos más o menos ambiciosos, ha acompañado a nuestros antepasados, empeñados en dotarse de instrumentos que mejorasen la calidad de vida. La imagen que acompañó a cada uno de los descubrimientos era, en general, positiva, aunque con alguna polémica, especialmente cuando acontecimientos muy relevantes (guerras mundiales...) mostraron que muchos de los avances y herramientas también servían para matar inocentes. No todo era progreso y había efectos negativos. El debate no se ha apagado y sigue vigente a las puertas de la tercera década del tercer milenio.

De esa época, de cuando cobró fuerza el debate sobre bondades y peligros de las tecnologías, datan los orígenes de la red de redes. Internet, como toda creación cultural, encierra herencias de sus mentores, de los actores que intervinieron en su desarrollo y del escenario en el que ha emergido. Lo aceptamos, aunque sabemos que en su desarrollo, su gobierno y la búsqueda de su control hay muchos actores implicados e interesados, que siguen aplicando estrategias para cuestionar todo lo que se aproxime a la defensa de la denominada neutralidad de la red. Quizá por ello los resultados no se corresponden con los esperados por muchos de los que han contribuido a su nacimiento y quizás por ello hay una gran distancia entre lo que puede aportar y lo que realmente consigue aportar a un mundo mejor comunicado. 
Al final, dos visiones sobre la tecnología, las que entienden los avances como superación de obstáculos y renovadas conquistas a favor del progreso y del bienestar de los ciudadanos y las que inciden en los peligros que entrañan muchas de las herramientas, mantienen un pulso por persuadirnos sobre las certezas de sus posiciones. Muy pocas veces y en muy pocos ámbitos (con muy contados protagonistas) dialogan. Su principal preocupación reside en ganar la batalla de la opinión publicada y pública.

Los defensores del desarrollo tecnológico como liberación de duras cargas para los humanos y como vía para el desarrollo y la mejora de las condiciones de vida de la Humanidad cuentan con muchos argumentos a su favor. No albergamos dudas. Es suficiente con un recorrido por los avances para comprender como las máquinas realizan algunos de los más duros trabajos que durante años han hecho las personas. Lo mismo podemos decir del campo de la comunicación, donde la digitalización, que abarca todas las esferas de la vida humana, alimentó una gran revolución de la accesibilidad. la movilidad y la automatización forman parte.

Los que se aproximan a las tecnologías con menos entusiasmo tecnoglobalista y con más reflexión crítica han comenzado advirtiendo de las brechas generadas, en especial digitales, y las consecuencias en nuestros comportamientos, desde las adicciones hasta alteraciones en la salud de las personas. Las TIC y la sociedad red no solo han traído bienestar, sino nuevos procesos y efectos en la sociedad, muchos todavía poco estudiados. No se trata, por tanto, de una estigmatización de las TIC por algunas de las consecuencias de sus usos (o malos usos), sino impulsar la reflexión crítica que contemple y analice fortalezas y debilidades.

La última palabra sobre las consecuencias de las tecnologías de la información y la comunicación no está escrita ni se espera la aparición de remedios mágicos. Es cierto que algunos actores llegaron tarde a la revolución tecnológica y que importantes actores del campo de la comunicación mediada tecnológicamente no valoraron correctamente el impacto en sus proyectos y negocios, pero no cabe duda que la práctica totalidad de los integrantes del ecosistema comunicativo han tenido que subirse a un carro, el de la tecnología digital, que, para sacarle el máximo rendimiento a favor de los intereses de los ciudadanos y de los servicios públicos, es necesario entender no solo la complejidad de las herramientas que lo conforman sino las consecuencias y las medidas necesarias para que estén al servicio de la mayoría y no solo de unos pocos que se consideran sus dueños.

Las herramientas de comunicación de la sociedad red pueden ser un instrumento de liberación, como apunta Manuel Castells, pero también un instrumento de vigilancia y control, como señalan Armand Mattelart y André Vitalis. Hay ejemplos de movimientos sociales que han empleado acertadamente las herramientas y canales de la sociedad red, de casos de empoderamiento ciudadano o de renovadas vías para hacer que la voz de pequeños colectivos llegue al escenario glocal. Pero también disponemos de ejemplos de cibercontrol, de vulneración de derechos básicos de los ciudadanos mediante herramientas tecnológicas o de consecuencias negativas en diferentes capas de la población. 
Del análisis de las investigaciones y reflexiones de Castells o Mattelart, como de otros muchos investigadores en ciencias sociales que han aportado conocimiento en las últimas décadas, podemos concluir que, por mucha alfabetización digital de tengamos y por muy bien que empleemos nuestras competencias y habilidades digitales en nuestras actividades, difícilmente podremos escapar de sus dimensiones más negativas. Su doble cara las acompaña y a sus consecuencias debemos enfrentarnos cuando hagamos cualquier intento para ponerlas al servicio de una sociedad más justa y mejor comunicada e informada.

\section{BREVE SEMBLANZA DEL AUTOR:}

Xosé López, catedrático de Periodismo y periodista, dirige el grupo de Investigación de la Universidad de Santiago de Compostela y, en la actualidad, es director del Departamento de Ciencias de la Comunicación. Sus líneas de investigación se enmarcan en los campos de los estudios periodísticos, de la cultura digital y de la comunicación y la cultura en Galicia. En los últimos años ha dirigido varios proyectos sobre el impacto de las tecnologías actuales en los procesos comunicativos y, sobre todo, en las prácticas periodísticas y en la definición de renovados perfiles profesionales. En la actualidad es el investigador principal de un proyecto sobre periodismo móvil.

\section{Versión en Gallego: A DOBRE CARA DAS TECNOLOXÍAS DA COMUNICACIÓN: LIBÉRANNOS E CONTRÓLANNOS}

Dúas dimensións das tecnoloxías da información e a comunicación (TIC) convertéronse noutros tantos alicerces que alimentan o imaxinario da sociedade rede nos tempos da denominada automatización intelixente. Libérannos e empoderannos no escenario dixital, pero ao mesmo tempo contrólannos e, ás veces, desconcértannos. Do mesmo xeito que o deus Jano na mitoloxía romana, ofrecen dúas caras que representan fortalezas e ameazas do pasado e do futuro.

Das diversas fases tecnolóxicas que marcaron a historia da Comunicación, a actual, que emerxe ao redor das TIC, a dixitalización, internet e a sociedade rede, non só conseguiu cambiar paradigmas senón que fixo posible que as audiencias sexan realmente activas e que a autocomunicación ocupe un lugar relevante no ecosistema mediático.

Paralelamente, nestes anos vimos como o software consolidou a súa posición no vértice do mando.

Desde as súas orixes, a tecnoloxía xurdiu como a resposta e construción dos humanos a necesidades ou desafíos. O reto da superación, con obxectivos máis ou menos ambiciosos, acompañou aos nosos antepasados, empeñados en dotarse de instrumentos que mellorasen a calidade de vida. A imaxe que acompañou a cada un dos descubrimentos era, en xeral, positiva, aínda que con algunha polémica, especialmente cando acontecementos moi relevantes (guerras mundiais...) mostraron que moitos dos avances e ferramentas tamén servían para matar inocentes. Non todo era progreso e había efectos negativos. O debate non se apagou e segue vixente ás portas da terceira década do terceiro milenio. 
Desa época, de cando cobrou forza o debate sobre bondades e perigos das tecnoloxías, datan as orixes da rede de redes. Internet, como toda creación cultural, encerra herdanzas dos seus mentores, dos actores que interviñeron no seu desenvolvemento e do escenario no que emerxeu. Aceptámolo, aínda que sabemos que no seu desenvolvemento, no seu goberno e a procura do seu control hai moitos actores implicados e interesados, que seguen aplicando estratexias para cuestionar todo o que se aproxime á defensa da denominada neutralidade da rede. Quizá por iso os resultados non se corresponden cos esperados por moitos dos que contribuíron ao seu nacemento e quizais por iso hai unha gran distancia entre o que pode aportar e o que realmente consegue aportar a un mundo mellor comunicado.

Ao final, dúas visións sobre a tecnoloxía, as que entenden os avances como superación de obstáculos e renovadas conquistas a favor do progreso e do benestar dos cidadáns e as que inciden nos perigos que entrañan moitas das ferramentas, manteñen un pulso por persuadirnos sobre as certezas das súas posicións. Moi poucas veces e en moi poucos ámbitos (con moi contados protagonistas) dialogan. A súa principal preocupación reside en gañar a batalla da opinión publicada e pública.

Os defensores do desenvolvemento tecnolóxico como liberación de duras cargas para os humanos e como vía para o desenvolvemento e mellóra das condicións de vida da Humanidade contan con moitos argumentos ao seu favor. Non albergamos dúbidas. É suficiente cun percorrido polos avances para comprender como as máquinas realizan algúns dos máis duros traballos que durante anos fixeron as persoas. O mesmo podemos dicir do campo da comunicación, onde a dixitalización, que abarca todas as esferas da vida humana, alimentou unha gran revolución das que a accesibilidad. a mobilidade e a automatización forman parte

Os que se aproximan ás tecnoloxías con menos entusiasmo tecnoglobalista e con máis reflexión crítica comezaron advertindo das brechas xeradas, en especial dixitales, e as consecuencias nos nosos comportamentos, desde as adiccións ata alteracións na saúde das persoas. As TIC e a sociedade rede non só trouxeron benestar, senón novos procesos e efectos na sociedade, moitos aínda pouco estudados. Non se trata, xa que logo, dunha estigmatización das TIC por algunhas das consecuencias dos seus usos (ou malos usos), senón impulsar a reflexión crítica que contemple e analice fortalezas e debilidades.

A última palabra sobre as consecuencias das tecnoloxías da información e a comunicación non está escrita nin se espera a aparición de remedios máxicos. É certo que algúns actores chegaron tarde á revolución tecnolóxica e que importantes grupos do campo da comunicación mediada tecnoloxicamente non valoraron correctamente o impacto nos seus proxectos e negocios, pero non cabe dúbida que a práctica totalidade dos integrantes do ecosistema comunicativo tiveron que subirse a un carro, o da tecnoloxía dixital, que, para sacarlle o máximo rendemento a favor dos intereses dos cidadáns e dos servizos públicos, é necesario entender non só a complexidade das ferramentas que o conforman senón as consecuencias e as medidas necesarias para que estean ao servizo da maioría e non só duns poucos que se consideran os seus donos.

As ferramentas de comunicación da sociedade rede poden ser un instrumento de liberación, como apunta Manuel Castells, pero tamén un instrumento de vixilancia e control, como sinalan Armand Mattelart e André Vitalis. Hai exemplos de movementos 
sociais que empregaron acertadamente as ferramentas e canles da sociedade rede, de casos de empoderamento cidadán ou de renovadas vías para facer que a voz de pequenos colectivos chegue ao escenario glocal. Pero tamén dispoñemos de exemplos de cibercontrol, de vulneración de dereitos básicos dos cidadáns mediante ferramentas tecnolóxicas ou de consecuencias negativas en diferentes capas da poboación.

Da análise das investigacións e reflexións de Castells ou Mattelart, como doutros moitos investigadores en ciencias sociais que aportaron coñecemento nas últimas décadas, podemos concluír que, por moita alfabetización dixital que teñamos e por moi ben que empreguemos as nosas competencias e habilidades dixitales nas nosas actividades, dificilmente poderemos escapar das súas dimensións máis negativas. A súa dobre cara acompáñaas e ás súas consecuencias debemos enfrontarnos cando fagamos calquera intento para poñelas ao servizo dunha sociedade máis xusta e mellor comunicada e informada.

Xosé López é catedrático de Xornalismo na Universidade de Santiago de Compostela e coordinador do grupo de investigación Novos Medios

Ámbitos. Revista Internacional de Comunicación, n.40, edición de primavera, 2018. 